\title{
An Exploration of Graduate Level Agricultural Leadership Course Descriptions
}

\author{
A. Muscato ${ }^{1}$, M. Sowcik ${ }^{2}$, R. Williams ${ }^{3}$
}

\section{Abstract}

Since its introduction into agricultural education programs in the 1970s, agricultural leadership has continued to change due to the needs of students and trends within the field (Cletzer et al., 2020; Jones, 2004; Williams, 2007). A single research question guided the study: What is the nature of graduate agricultural leadership courses offered in the United States? This study utilized a qualitative content analysis to capture the meanings, emphasis, and themes of agricultural leadership graduate course descriptions. The frame for this research was established by consulting the American Association of Agricultural Educators member list. University course catalogs were reviewed, and all graduate coursework offered by the agricultural education departments of the identified institutions that included any of the following terms in the title were noted: (a) lead, (b) leader, and (c) leadership. A total of 62 courses from 11 institutions met the criteria. The findings clustered the courses into 21 categories, further compiled into six themes: (1) individual-level focus, (2) organizational-level focus, (3) societal-level focus, (4) professional focus, (5) methodological focus, (6) developmental focus. The findings and recommendations should be considered by agricultural leadership educators as they evaluate how to most appropriately grow their academic programs and coursework.

\section{Keywords}

Content analysis, graduate courses, leadership education, curriculum

1. Annie Muscato, Graduate Research Assistant, University of Florida, PO Box 112060 Gainesville, FL 32611, afmuscato@ufl.edu iD https://orcid.org/0000-0001-9936-9374

2. Matthew Sowcik, Assistant Professor, University of Florida. PO Box 112060 Gainesville, FL 32611, sowcik@ufl.edu (iD) https://orcid.org/0000-0002-5630-2281

3. Rebecca Williams, Visiting Assistant Professor, University of Florida, , PO Box 112060 Gainesville, FL 32611, rjwillia@ufl.edu (D) https://orcid.org/0000-0003-3849-9348 


\section{Introduction and Problem Statement}

Leadership education provides students with the skills to effectively engage with organizations, establish meaningful dialogs, increase their ability to fulfill leadership roles, and expand their capacity for thoughts and ideas (Huestedde \& Woodward, 1996; McCauley, et al., 1998; Day, 2000). Additionally, when exposed to leadership theory and practice, students are better suited to assume leadership roles within their community and contribute to the growth of businesses, industry, and community development (Kristick, 2009; Russon \& Reinelt, 2004). The field of agriculture is no exception to these benefits (Weeks et al., 2020). Those working in this context continually face complex problems such as climate change, droughts, flooding, and water scarcity, requiring strong leadership (Jordan et al., 2013).

Since its introduction into agricultural education programs in the 1970s, agricultural leadership has continued to change to meet the needs of students and industry (Cletzer et al., 2020; Jones, 2004; Williams, 2007). One of the major changes that occurred in agricultural leadership was the inclusion of the discipline in graduate agricultural education (Jones, 2004). However, despite the growth of these programs, there exists a scarcity of research on the topic in this context. As agricultural leadership graduate programs further develop, research is critical to better understand both the current state of the field and changes needed to improve the educational outcomes of programs. As Alexander (2015) suggests, "Having a better understanding of agricultural leadership-related programming will be an asset to the discipline regarding restructuring programs to students' needs, creating growth among academic programs, and increasing the knowledge of educators within the field" (Alexander, 2015, p. 26). The current study provides insight into graduate level agricultural leadership coursework in the United States and explores how the coursework fulfills the needs of the agricultural industry.

\section{Theoretical and Conceptual Framework}

This study utilized Finch and Crunkilton's (1999) program systems model (PSM) as its conceptual framework (see Figure 1). The PSM describes a basic feedback loop using a systems approach demonstrating how academic programs revise the process by which they educate students using new information (Finch \& Crunkilton, 1999). This model has been used repeatedly as the framework for examination of agricultural education and communication programs over the course of the last ten years. Cannon et al. (2016) used it to develop a national portrait of undergraduate agricultural communication courses. Morgan et al. (2013) used the model to explore elements of undergraduate agricultural leadership programs. Additionally, research has been conducted within the field of agricultural education related specifically to each component of the model. Specifically, Watson and Robertson's (2011) research on students, Morgan and Rucker's (2013) research on faculty, and Morgan's (2012) research on graduates. 
Figure 1

Program Systems Model

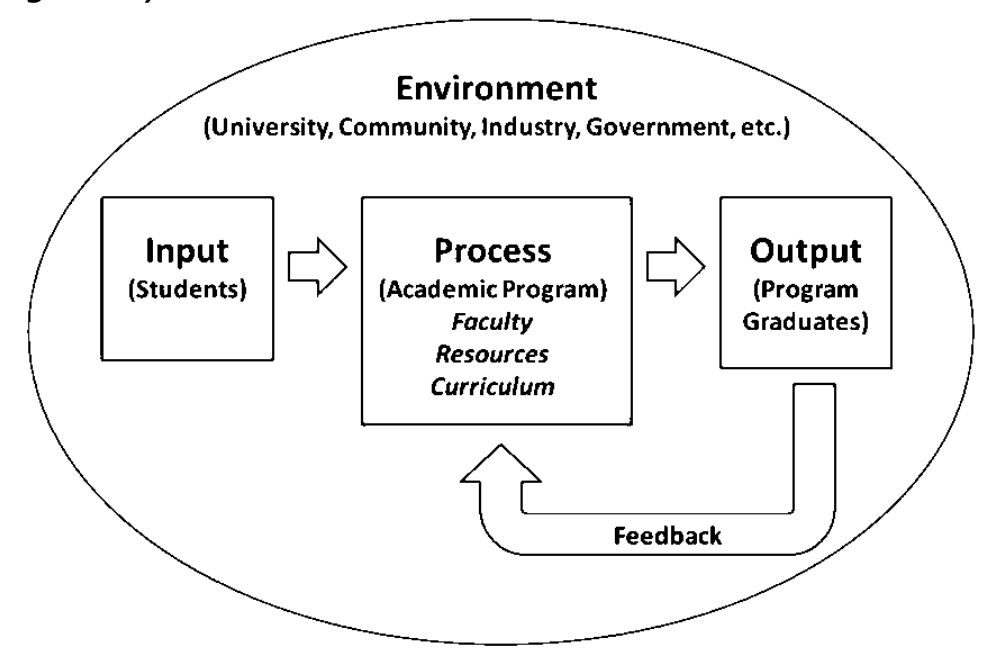

Note. Adapted from "Curriculum Development in Vocational and Technical Education, Planning, Content, and Implementation," by C. R. Finch and J. R. Crunkilton, 1999, Allyn and Bacon.

In this study, the model's systems theory approach was employed to understand how graduate level agricultural leadership programs are operating within and influenced by the external environment. Specifically, this study will utilize the curriculum component of the process portion of the model, as it is directly related to programmatic coursework. In Cletzer et al. (2020) the model was used similarly to explore the scope and nature of undergraduate agricultural leadership coursework. This consistency between approaches for the latter previous research and the current study allow for a holistic discussion regarding the development of agricultural leadership programs in higher education.

\section{Purpose}

The purpose of this study was to contribute to the scarce research on agricultural leadership education programs by identifying themes between graduate level course descriptions. The importance of the programs themselves is captured by Research Priority 3 of the American Association for Agricultural Education's National Research Agenda. and tasks agricultural educators with preparing graduates with 21st century skills, such as leadership (Roberts et al., 2016). An overarching research question guided the study: What is the scope and nature of graduate agricultural leadership courses offered in the United States?

\section{Methods}

\section{Research Design}

This study utilized a qualitative content analysis, defined by Krippendorff (2004) as, "a research technique for making replicable and valid inferences from texts (or other meaningful matter) to 
the contexts of their use" (p. 18). The purpose of qualitative content analysis is to, "capture the meanings, emphases, and themes of messages to understand the organization and process of how they are presented" (Altheide, 1996, p. 33). Additionally, Knapp (2017) argues the study of leadership education is uniquely appropriate to be approached qualitatively. Therefore, this qualitative design was most appropriate to capture the meanings, emphasis, and themes of agricultural leadership graduate coursework.

\section{Data Sources and Collection}

The frame for this research consisted of all departments or programs in the United States currently offering agricultural leadership programs at the graduate level. The population frame was established by consulting the American Association of Agricultural Educators (AAAE) member list and determining who self-identified as offering a masters or doctoral degree or graduate level specialization in agricultural leadership. Eleven institutions were identified: 1. University of Florida, 2. University of Kentucky, 3. University of Nebraska, 4. Ohio State University, 5. Oklahoma State University, 6. University of Tennessee, 7. Texas A\&M University, 8. Virginia Polytechnic Institute and State University, 9. Oregon State University, 10. Georgia State University and 11 . University of Missouri. Publicly available university graduate course catalogs were reviewed, and all graduate coursework offered by the agricultural education departments of those institutions that included any of the following terms in the course title were noted: (a) lead, (b) leader, and (c) leadership. Then, the corresponding course descriptions were collected. University course descriptions provided a summary of course purpose and objectives making them an appropriate data set for broadly understanding graduate level agricultural leadership courses in the United States. A total of 62 courses met the criteria and were included in the study.

\section{Data Analysis}

After initial collection the data was first analyzed to determine a variety of factors. These included the number of graduate level agricultural leadership courses offered by the individual institutions and how often the terms: (a) agriculture, (b) natural resources, (c) Extension, and (d) agricultural education were included in the course descriptions. Since the literature indicates a potential disconnect between the study of leadership and agricultural leadership specifically, these terms were important to understand if leadership courses were including an agricultural and/or life science focus. While qualitative content analysis is not often focused on quantification of individual words or terms, Krippendorff (2004) argued the two are inextricably linked when he stated, "ultimately, all reading of texts is qualitative, even when certain characteristics of a text are later converted into numbers" (p. 16).

Next, a qualitative content analysis approach was used to identify patterns within the course descriptions. Following the recommendations of Krippendorff's (2004) hermeneutic loop the researcher engaged in an iterative process of reviewing and re-reviewing the entirety of the data while continuously re-contextualizing, reinterpreting, and redefining it. The intention of this was to construct themes from the content using an abductive research approach as suggested by Delputte and Orbie (2017). From this the researcher compiled a list of codes for categories all the courses would fit into. Leaning on previous research of agricultural leadership 
courses these categories were compared to Cletzer et al. (2020) and then compiled into corresponding themes.

\section{Limitations}

It is worth noting one institution included in the study had no leadership courses listed within the agricultural education department and another had only one. Presumably there is an explanation for these outliers, but based strictly on content analysis, that is impossible to know. This method is highly effective for categorizing data, as was done in this study, but the results lack the thick rich description qualitative research is known for. Additionally, a lack of publicly available access to up-to-date syllabi made it impossible to include course syllabi in this study. However, it was determined that course descriptions are intended to serve as an outline of both the purpose and objectives of courses, thus serving the research purpose sufficiently.

\section{Findings}

Of the 11 institutions listed as having graduate level agricultural leadership programs in the AAAE membership directory, $90.9 \%(n=10)$ list at least one graduate level leadership course housed within their agricultural education department in their university course catalog. Total number of graduate level agricultural leadership courses offered nationwide was 62. Number of courses offered per institution ranged from 0 to 15 with a median of 5 and mean of 5.64.

When examining the intentionality of connecting the leadership courses specifically to agricultural and life sciences, only $41.9 \%(n=26)$ of the courses included the terms: (a) agriculture, (b) natural resources, (c) Extension, and/or (d) agricultural education in the course description found in the university course catalog. Respectively, each term occurred in a course description the following number of times: (a) agriculture $=16$, (b) natural resources $=3$, (c) Extension $=10$, and $(\mathrm{d})$ agricultural education $=11$.

The content analysis of course descriptions resulted in 62 courses fitting into 21 distinct categories. These were further compiled into six overarching themes specifying the shared collective focus of the course categories (see Table 1). Because the categories and themes so closely aligned with Cletzer et al.'s (2020) findings, the researcher used their established definition of themes. This provides important consistency of language to national conversations about agricultural leadership programs.

\section{Description of Themes}

1. Individual-level Focus: "...courses focused on the individual student, such as introductory courses designed to provide a survey of leadership theories, or personal leadership courses designed to help students discover their individual leadership strengths, styles, or values" (Cletzer et al., 2020. p. 4).

2. Organizational- level Focus: “...courses designed to improve bounded systems, such as teams, organizations, and communities" (Cletzer et al., 2020. p. 4). 
3. Societal- level Focus: "...courses discussing how leadership impacts broad societal issues, such as diversity, change, and ethics" (Cletzer et al., 2020. p. 4).

4. Professional Focus: "...courses intended to prepare students for leadership roles specifically as agriculture teachers, or more broadly in the agriculture industry" (Cletzer et al., 2020. p. 6).

5. Methodological Focus: "...defined by the structure of the course, rather than content or focus" (Cletzer et al., 2020. p. 6).

6. Developmental Focus: “...courses related to teaching students to develop, deliver, and manage leadership programming. A distinction was made between courses focusing exclusively on youth and those intended for broader applications" (Cletzer et al., 2020, p. 6).

The range of courses making up each individual theme was 8-13, indicating the courses were distributed among the themes relatively evenly. The mean number of courses in each theme was 10.3 and the median number of courses was 10 . However, the number of courses offered nationwide, when examined by category, was much more varied. The range in number of courses offered per each of the 21 categories identified was 1-8 while the mean number of courses per category was only 2.95 and median only 2 . 


\section{Table 1}

Organization of leadership courses by category and theme

\begin{tabular}{|c|c|c|c|}
\hline Theme & Category & $\begin{array}{l}\text { Number of } \\
\text { Courses by } \\
\text { Theme }\end{array}$ & $\begin{array}{l}\text { Number of } \\
\text { Courses by } \\
\text { Category }\end{array}$ \\
\hline \multirow[t]{2}{*}{ Individual-level Focus } & Introduction to Leadership Theory & 9 & 8 \\
\hline & Personal Leadership Development & & 1 \\
\hline \multirow{5}{*}{$\begin{array}{l}\text { Organizational-level } \\
\text { Focus }\end{array}$} & Organizational Leadership & 10 & 5 \\
\hline & Development & & \\
\hline & Leadership and Community & & 3 \\
\hline & Development & & \\
\hline & Team and Group Leadership & & 2 \\
\hline \multirow[t]{4}{*}{ Societal-level Focus } & Global & 8 & 3 \\
\hline & Diversity and Culture & & 2 \\
\hline & Ethics & & 2 \\
\hline & Change & & 1 \\
\hline \multirow[t]{4}{*}{ Professional Focus } & Leadership in Agriculture & 12 & 6 \\
\hline & Agricultural Teacher Preparation & & 4 \\
\hline & Communications and Leadership & & 1 \\
\hline & Leadership for General Career & & 1 \\
\hline \multirow[t]{6}{*}{ Methodological Focus } & Interdisciplinary & 13 & 3 \\
\hline & Research Methods & & 3 \\
\hline & Individual Study & & 2 \\
\hline & Critical Leadership Studies & & 2 \\
\hline & Single Theory Focus & & 2 \\
\hline & Seminar & & 1 \\
\hline \multirow[t]{2}{*}{ Developmental Focus } & $\begin{array}{l}\text { Program Development, Delivery, } \\
\text { and Volunteer Management }\end{array}$ & 10 & 7 \\
\hline & Youth Leadership Development & & 3 \\
\hline
\end{tabular}

\section{Conclusions, Discussion, and Recommendations}

The results of this study indicate that the number of graduate level agricultural leadership courses offered in the United States has increased by $82.4 \%(n=28)$, since 2003 when Fritz et. 
al. identified 34 graduate leadership courses offered by agricultural education programs. When considering the results of this study through the lens of the Finch and Crunkilton's (1999) Program System's Model, the model suggests academic programs are influenced by their own faculty, graduates, and industry representatives. The results of this study, however, do not correspond with Jones (2004) findings identifying what leadership traits faculty members and industry representatives' rate as important for graduates to possess. Both groups agreed the three most important traits for graduates were communication, interpersonal relationship building, and collaboration. Therefore, Program Systems Model would suggest the categories corresponding to those traits would have an above average number of courses included in them.

In the current study, the communications and leadership category includes only one course, and the team and group leadership category, which would apply to both interpersonal relationship building and collaboration, includes only two courses. In both of these categories less than the mean number of courses $(n=2.95)$ are included. To determine what the focus of graduate level agricultural leadership courses are in the United States, we must look to the categories with the greatest number of courses. Of all 62 courses, $48.0 \%$ of them $(n=30)$ fall under five of the 21 total categories. The five categories and the number of courses includes: (1) individual-level focus ( $n=8),(2)$ program development, delivery, and volunteer management $(n=7)$, (3) leadership in agriculture $(n=6)$, (4) organizational leadership development $(n=5)$, and (5) agricultural teacher preparation $(n=4)$.

Additionally, when considering content, it is important to consider how few courses included the terms: (a) agriculture, (b) natural resources, (c) Extension, and/or (d) agricultural education in the course description. Despite $100 \%$ of the analyzed courses $(n=62)$ being offered within Colleges of Agricultural and Life Sciences, by agricultural education departments, only 41.9\% ( $n$ $=26$ ) included any of the terms. Based upon the growth of agricultural leadership programs identified by this study and the literature, graduate level agricultural leadership programs should continue to be examined more in depth. A valuable contribution to the national conversation about the future of agricultural leadership education would be to determine if the direction the field is being managed intentionally in program design and delivery. Finally, research on agricultural leadership programs should consider the role context and contextual expertise (Kellerman, 2014) has on leadership education in an agricultural context. To best meet the unique challenges of the agricultural industry, should coursework focus on leadership education through an agricultural lens? Research into this area would provide agricultural leadership faculty insight into the need to introduce context specific areas like agriculture, natural resources, or Extension into the leadership education curriculum. It is possible that being housed within agricultural education departments in colleges of agricultural and life sciences is not enough if faculty members aren't engaging students in examination of leadership challenges or development of skills specific to agricultural industry needs.

Over the past five decades, the number of agricultural leadership programs have continued to increase within higher education. Over that time, these programs continued to change and evolve to address the needs and interests of those in academia and industry. While those 
working within the discipline have recognized a need for research and possibly standardization within agricultural leadership programs, the research is still in its infancy. The current study looked to add to the body of knowledge on agricultural leadership programs by providing an overview of themes found in graduate level course descriptions. This research is a first step to address commonalities and differences within agricultural leadership programs and purposefully move the discipline forward.

\section{References}

Alexander, J. (2015). Perceptions of agricultural leadership academic programs at 1862 landgrant universities [Master's thesis, University of Arkansas]. ScholarWorks. http://scholarworks.uark.edu/etd/1394

Altheide, D. L. (1996). Qualitative media analysis. Sage Publications.

Brown, F. W., \& Fritz, S. M. (1994). Determining the breadth of leadership and human resource management/development offerings in post-secondary departments of agricultural education. Journal of Agricultural Education, 35(3), 1-5. https://doi.org/10.5032/jae.1994.03001

Brungardt, C., Greenleaf, J., Brungardt, C., \& Arensdorf, J. (2006). Majoring in leadership: A review of undergraduate leadership degree programs. Journal of Leadership Education, 5(1), 4-25. https://journalofleadershiped.org/wpcontent/uploads/2019/02/5 1 Brungardt Greenleaf Brungardt Arensdorf.pdf

Cannon, K. J., Specht, A. R., \& Buck, E. (2016). Agricultural communications programs: A national portrait of undergraduate courses. Journal of Applied Communications, 100(1), 22-32. http://digitalcommons.unl.edu/aglecfacpub/80

Cletzer, D., Mott, R., Simonsen, J., Tummons, J., Peckman, J., \& Preston, K. (2021, May 24-27). Agricultural leadership: A national portrait of undergraduate courses. [Paper Presentation]. Annual Meeting of the North-Central American Association for Agricultural Education, Virtual.

Connors, J., \& Swan, B. (2006). A synthesis of leadership development research. Journal of Agricultural Education, 47(2), 1-13. https://doi.org/10.5032/jae.2006.02001

Crawford, P., Lang, S., Fink, W., Dalton R., \& Fielitz, L. (2011). Comparative analysis of soft skills: What is important for new graduates? https://www.aplu.org/members/commissions/food-environment-and-renewableresources/CFERR Library/comparative-analysis-of-soft-skills-what-is-important-for-newgraduates/file 
Day, D. V. (2000). Leadership development: A review in context. Leadership Quarterly, 11(4), 581-613. https://doi.org/10.1016/S1048-9843(00)00061-8

Delputte, S., \& Orbie, J. (2017) EU development policy: Abduction as a research strategy. In H. Heinelt, \& S. Münch (Eds.), Handbook of European Policy: Formulation, Development and Evaluation (pp. 288 - 305) Edward Elgar. http://hdl.handle.net/1854/LU-8590074

Dooley, K. E., \& Lindner, J. R. (2002). Competency-based behavioral anchors as authentication tools to document distance education competencies. Journal of Agricultural Education, 43(1), 24-35. https://doi.org/10.5032/jae.2002.01024

Finch, C. R., \& Crunkilton, J. R. (1999). Curriculum development in vocational and technical education, planning, content, and implementation. Allyn and Bacon.

Fritz, S. M., \& Brown, F. W. (1998). Leadership education courses and programs in departments of agricultural education. Journal of Agricultural Education, 39(3), 57-62. Https://doi.org/10.5032/jae.1998.03057

Fritz, S., Townsend, C., \& Hoover, T. (2003). An analysis of leadership offerings in collegiate agricultural education departments. North American Colleges and Teachers of Agriculture Journal, 47(3), 18-22. https://www.jstor.org/stable/43765775

Hustedde, R. J., \& Woodward, A. (1996). Designing a rural leadership program and curriculum. University of Kentucky Cooperative Extension Service. http://www2.ca.uky.edu/agcomm/pubs/ip/ip54/ip54.pdf

Jones, L. (2004). Academia and industry perspectives on leadership and human resource development competencies required for agricultural leadership graduate students pursuing industry careers [Unpublished doctoral dissertation, University of Florida]. http://etd.fcla.edu/UF/UFE0001294/jones I.pdf

Jordan, P. J., Buchanan, G. A., Clarke, N. P., \& Jordan, K. C. (2013). Leadership in agriculture: Case studies for a new generation. AgriLife Research and Extension Service Series, Texas A\&M Press. https://www.amazon.com/Leadership-Agriculture-Generation-AgriLifeExtension/dp/1603449418?asin=1603449418\&revisionld=\&format=4\&depth=1

Kaufman, E., Rateau, R., Ellis, K., Kasperbauer, H., \& Stacklin, L. (2010). Leadership program planning: Assessing the needs and interests of the agricultural community. Journal of Leadership Education, 9(1), 122-143.

Kellerman, B. (2014). Hard times: leadership in America. Stanford University Press. 
Knapp, M. S. (2017). The Practice of designing qualitative research on educational leadership: Notes for emerging scholars and practitioner-scholars. Journal of Research on Leadership Education, 12(1), 26-50. https://doi.org/10.1177/1942775116647365

Kouzes, J., \& Posner, B. (1997). The leadership challenge: How to keep getting extraordinary things done in organizations (3rd ed.). Jossey-Bass

Krippendorff, K. (2004). Content analysis: An introduction to its methodology (2nd ed.). Sage.

Lincoln, Y. S., \& Guba, E. G. (1985). Naturalistic inquiry. Sage Publications.

Lindner, J. R., \& Baker, M. (2003). Agricultural education competencies: A comparison of master's students at Texas Tech and Texas A\&M Universities. Journal of Agricultural Education, 44(2), 50-60. https://doi.org/10.5032/jae.2003.02050

McCauley, C. D., Moxley, R. S., \& Van Velsor, E. (1998). The center for creative leadership handbook of leadership development. Jossey-Bass.

McLagan, P. (1989). Models for HRD practice. Training and Development Journal, 43(9), 49+. https://link.gale.com/apps/doc/A7695572/AONE?u=anon d3cabba2\&sid=googleSchola $\underline{\mathrm{r} \& \mathrm{xid}=\mathrm{c} 731221 \mathrm{f}}$

Moody, L. D. (2001). Identifying and prioritizing agriculture and natural resources curriculum needs of Nebraska secondary and post-secondary institutions [Dissertation, University of Nebraska - Lincoln]. DigitalCommons. https://digitalcommons.unl.edu/dissertations/AAl3022653/

Morgan, A. C. (2012). Competencies needed by agricultural communications undergraduates: A focus group study of alumni. Journal of Applied Communications, 96(2), 17-29.

Morgan, A. C., King, D. L., Rudd, R. D., \& Kaufman, E. K. (2013). Elements of an undergraduate agricultural leadership program: A Delphi study. Journal of Leadership Education, 12(1), 140-155.

Morgan, A. C., \& Rucker, K. J. (2013). Competencies needed by agricultural communications undergraduates: An academic perspective. Journal of Applied Communications, 97(1), 50-65.

Roberts, T. G., Harder, A., \& Brashears, M. T. (Eds). (2016). American Association for Agricultural Education national research agenda: 2016-2020. Department of Agricultural Education and Communication, University of Florida.

Russon, C., \& Reinelt, C. (2004). The results of an evaluation scan of 55 leadership development programs. Journal of Leadership and Organizational Studies, 10(3), 105-107. 
Simonsen, J., \& Birkenholz, R. (2010). Leadership courses required in agricultural teacher education programs. Journal of Agricultural Education, 51(3), 114-124. https://doi.org/10.5032/jae.2010.03114

Stedman, N., \& Weeks, P. (2013). The balancing act: Exploring scholarship for the agricultural leadership educator. Journal of Leadership Education, 12(3), 82-94.

Strickland, L. R., Carter, H. S., Harder, A., Roberts, G., \& Wysocki, A. (2010, February 7-8). Understanding the intended outcomes and impacts of agricultural leadership development programs. [Paper Presentation] Southern Association of Agricultural Scientists, Orlando, FL.

Velez, J. J., McKim, A. J., Moore, L. L., \& Stephens, C.A. (2015). A nationwide assessment of the scope and impact of agricultural leadership education. Journal of Agricultural Education, 56(1), 116-126. https://doi.org/10.5032/jae.2015.01116

Velez, J., Moore, L., Bruce, J., \& Stephens, C. (2014). Agricultural leadership education: Past history, present reality, and future directions. Journal of Leadership Studies, 7(4), 65-70. https://doi.org/10.1002/jls.21312

Watson, T., \& Robertson, J. T. (2011). Perceptions of agricultural communications freshmen regarding curriculum expectations and career aspirations. Journal of Applied Communications, 95(3), 6-20.

Weeks, W. G., \& Weeks, P. P. (2020). Agricultural sciences and natural resources: Developing future agricultural leaders. New Directions in Student Leadership, 2020(165), 37-48. https://doi.org/10.1002/yd.20367

Western, S. (2019). Leadership: A critical text. Sage Publications.

Williams, J. (2007). The conceptualization of leadership and leadership development by academic department heads in colleges of agriculture at land-grant institutions: A qualitative study [Unpublished doctoral dissertation]. Texas A\&M University.

Williams, J., Townsend, C., \& Linder, J. (2005). Teaching leadership: Do students remember and utilize the concepts we teach? Journal of Leadership Education, 4(1), 62-74.

(C) 2021 by authors. This article is an open access article distributed under the terms and conditions of the Creative Commons Attribution license (http://creativecommons.org/licenses/by/4.0/). 